\title{
Adaptation of form based code method in the Polish spatial planning system
}

\author{
Bartosz Kaźmierczak \\ https://orcid.org/0000-0001-8436-6963 \\ bartosz.kazmierczak@put.poznan.pl \\ Faculty of Architecture, Poznań University of Technology
}

\begin{abstract}
This paper aims to present a problematic issue of the spatial planning system in Poland in the context of landscape protection. In his research, the author proves that statutory spatial planning tools fail to be efficient in the area of aesthetic and spatial order. The author has analysed the provisions of the local laws on an example of a selected Polish municipality to answer the question whether local laws effectively protect local natural and cultural landscape that is a major factor for the development of sustainable tourism (a strategic aspect of the business activity in the municipality).
\end{abstract}

Keywords: spatial planning, urban form, spatial order, place identity

\section{The Polish system of spatial planning - problematic issues}

A multi-layered and complex urban structure (town) often assumes a form that is amorphous, deformed and non-homogeneous. Analysing the development of modern housing estates, we can see that, despite a number of attempts and efforts, they are never ideal spatial structures. Principles of shaping urban space set forth in the laws and technical regulations do not sufficiently protect urban landscape. Nevertheless, they can help to minimise the adverse effects of some disadvantageous aspects of investment projects [Jopek, 2015].

The Polish system of spatial planning faces a number of problems that have been discussed in numerous publications, research works and reports. ${ }^{1}$ One of them is improper wording of provisions, which e.g. allow for different interpretations thereof or in generally fail to define basic terms. As an example we can refer to terms concerning development that give rise to a great number of legal disputes, namely such terms as: freedom of development, good neighbourhood, continuation of functions or continuation of development. In a three year time span (2013-2016) at least one of the aforementioned terms was referred to in court decisions, respectively: freedom of development - 2851 times, good neighbourhood - 3504 times, continuation of functions -6096 times and continuation of development 4787 times [Kowalewski 2019].

The system of spatial planning in Poland is continuously evolving, however, none of the amendments of the Law of 27 March 2003 on spatial planning and development have introduced any major changes that might effectively protect spatial order and prevent excessive urban sprawl.

Among a number of different criteria of spatial order, proper representation of factors related to composition and aesthetics is one of the biggest problems in the urban planning practice because provisions fail to be unambiguously worded. The issues of building aesthetics seem to be of little interest to the legislator passing the Law on spatial planning and development. In practice this means that the administrative authority obliged to introduce regulations guaranteeing proper spatial order and sustainable development should first of all set forth the principles of shaping aesthetic order in the form of a general clause, effective outside the legal system. Only thereafter these norms should be transposed onto the statutory spatial planning tools and defined more precisely. [Woźniak, 2015] 
Unfortunately such a planning model is not in-line with an integrated, sustainable way of organisation of an urban planning process. Another problem arises due to zoning plans being adopted with no regards for the issues of aesthetics and composition. In 2015 the so-called Landscape Act was passed. Under the Act the issue of spatial forms in spatial planning was separated from the zoning plan issue, which as a result largely undermined the role of zoning plans in the shaping of spatial and aesthetic order.

\section{Form-based Code}

The main idea of New Urbanism envisages designing compact, mixed-use, vibrant and multi-functional spatial structures that pedestrians or cyclists can easily move within. The innovative approach in planning here is the discontinuation of the commonly used modern functional zones and adoption of the transect composed of a series of zones that transition from sparse rural development to the dense urban core.

Form-based code, is a planning tool allowing the designer to arrive at specified spatial development forms in compliance with the principles of sustainable development and spatial order. The main objective of FBC is to foster predictable spatial results and to create high quality public space by concentrating on the relationships between various spatial elements rather than on the functional purpose of a given area. [Duany, Plater - Zyberk, 2006].

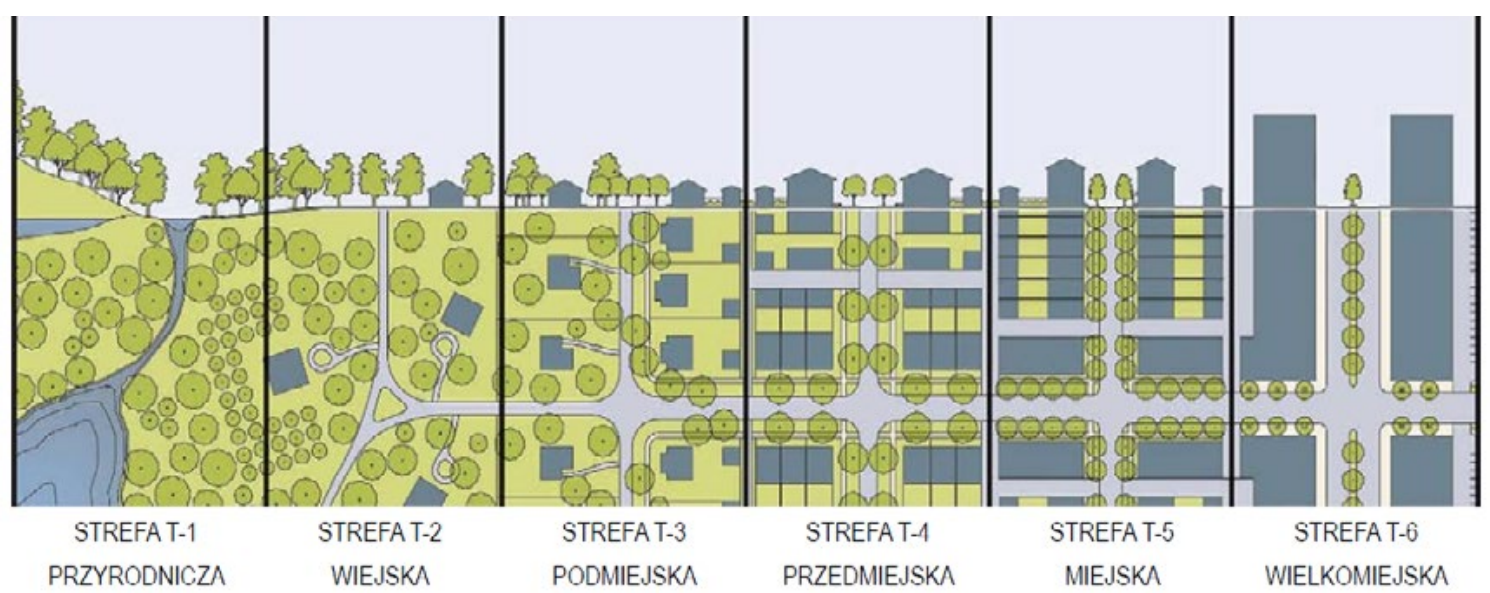

Fig. 1. A scheme of distribution of spatial structures in accordance with the transect idea ${ }^{2}$ [source: cnu.org]

FBC can be a useful planning tool for any acts aimed at the protection of spatial values of an area that is subject to relevant regulations. Traditional tools, such as the local zoning plan offer insufficient options of defining the desirable spatial forms and their interrelations. Problems stem from the fact that it is difficult to unambiguously and legibly word the provisions of the zoning plan in the sphere of defining architectural forms, construction materials to be used or the colour scheme to be applied.

FBC may prove to be a useful tool in reaching consensus in Polish conditions - in accordance with the principle of involvement of local communities in the planning process - in the context of spatial, social and economic effects of adopting a plan. The issue of involving local communities in the planning process underlies the concepts of the Form Based Code and sustainable planning, for that reason graphical representation of the set forth regulations facilitates a constructive dialogue between all the parties involved.

The key element in a discussion on sustainable development, being an alternative to dispersed development and urban sprawl, (which is often omitted in any public debates) is the presently applicable system of codes and standards governing the social development, which assumes (be it with or without purpose) the division 
of space in view of the area intended purpose. Such a system not only fails to render desirable spatial effects but largely contributes to profiteering and excessive exploitation of the existing resources [Jędraszko 2005].

Table 1. Author's own elaboration Sarasota Country FBC by Dover, Kohl \& Partners and Spikowski Planning Associates

\section{Form Based Code}

Priorities to be defined: form, function, administration

all the functions are allowed in every zone, except for those causing nuisance

regulation concerning the location of the building on the lot

regulation concerning the manner of shaping public space

allows for implementation of concepts of local communities

\section{Local Zoning Plan}

Priorities to be defined: function, administration, form

Mono-functional zones or zones with a predominant function and permissible supplementary functions

the line of development (and technical conditions) make up the only regulation

the road lane width makes up the only regulation secures the interests of individual investors

\section{Sustainable tourism in the municipality of Złoty Stok}

The municipality of Złoty Stok is situated in the southern part of Lower Silesia, in ząbkowicki poviat. It is $20 \mathrm{~km}$ away from Ząbkowice Śląskie and about $90 \mathrm{~km}$ away from Wrocław. Despite the fact that it is located near some of well-known tourist resorts in the area of the Kłodzko Valley (Polish: Kotlina Kłodzka), it is not so often visited by the tourists ${ }^{3}$. The sustainable development of the municipality based on tourism, agriculture and forestry as basic sectors of local business activity is the main concept of the Development Strategy for the municipality of Złoty Stok for the years 2017-2023. Assurance of the development of sustainable tourism in the municipality of Złoty Stok is extremely important because it is closely interrelated with the outstanding, though underappreciated, landscape values. The adopted document lists the following as the basic purposes of the development of the municipality: improvement of the quality of life of the inhabitants, revaluation of historical heritage, boosting local economy, improvement of the urban space quality, a more positive image of the town.

The strategic goals have been appropriately worded as they converge with the general principles of sustainable tourism, i.e.

- development of tourism is adapted to the types and quality of natural resources and may not contribute to their degradation,

- local community shall participate in all tourism-related activities undertaken in the area they inhabit,

a range of tourist services shall be based on local natural and human resources and small local facilities adjusted with their scale to the surroundings,

- development of tourism is integrated with local business development and renders ethical, social and economic benefits for the local community. [Gołębski, 2009]

- However, is proper wording of the strategic goals sufficient to obtain the desirable spatial, social and economic effects in the sector of sustainable development?

The development of sustainable tourism encompasses the idea of protection of unique features of cultural landscape. Cultural differences of a given place are closely correlated with the local natural conditions, which is demonstrated through the shape of development and the applied construction materials. This affects the specifics and the genius loci reflected in the cultural and territorial differences. Unique features of landscape 
translate into a phenomenon formed naturally within the on-going processes over the time span of several centuries. Such unique features shall, therefore, be protected before they perish [Pawłowska, 1996].
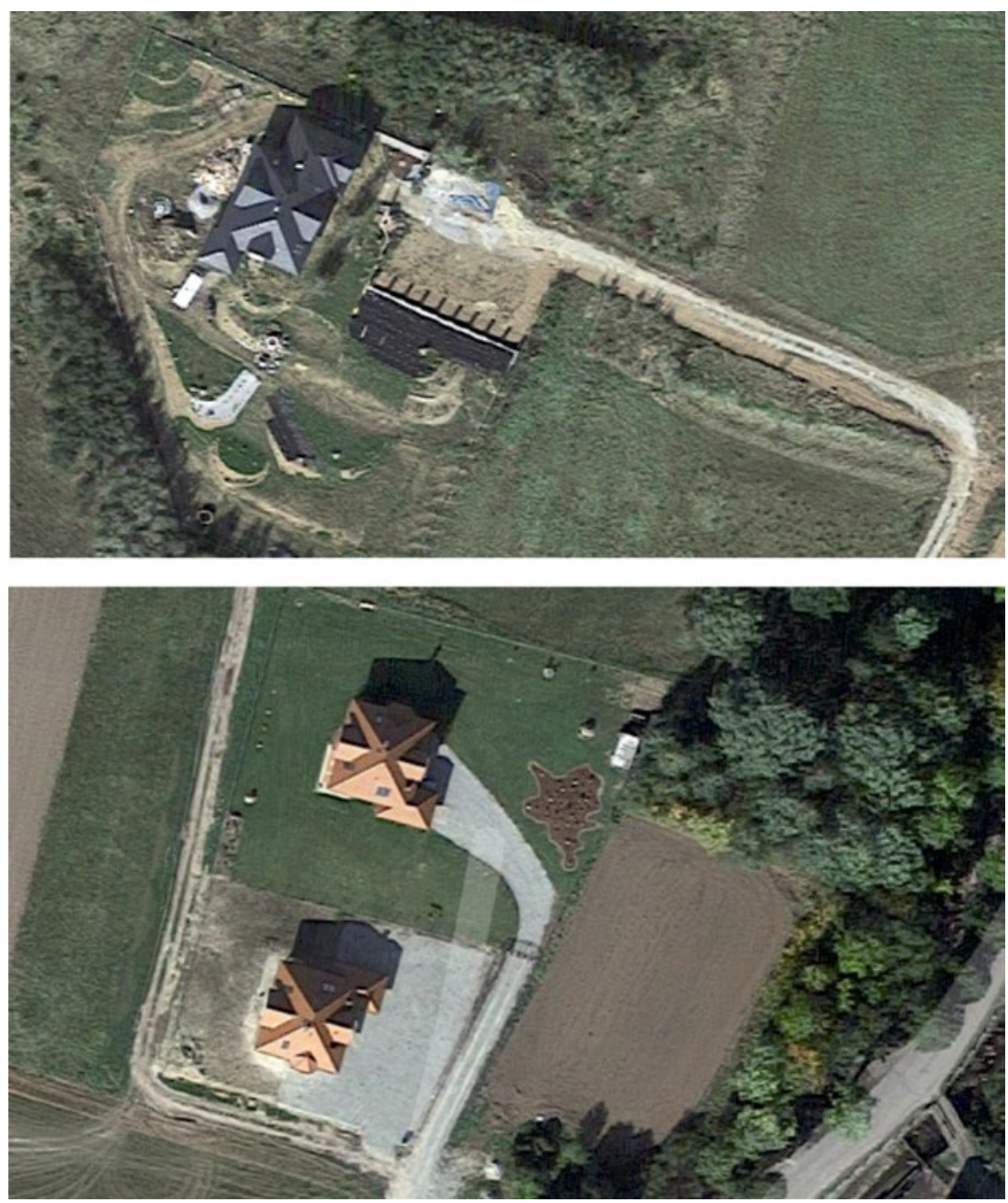

Fig. 2. Lack of expressly worded provisions concerning the nature of new development translates into erection of misfitted forms of development in the landscape of the municipality of Złoty Stok. [photo from google.maps]

From the perspective of cultural heritage, historical spatial layouts of the village and town of Złoty Stok, together with the preserved architecture, typical of that part of Lower Silesia, shall be of high value. Lack of excessive investment pressure has to a large extent prevented the landscape from being marred with any atypical, ill-suited forms of development, on the other hand, economic stagnation let the technical condition of the existing historical facilities largely deteriorate. Some of them require heavy repairs and renovation but some have been irretrievably changed in the course of construction works completed contrary to professional building practice.

Designing and promoting tourist products which focus on spatial order - in particularly in the perspective of aesthetics and landscape - is of key importance for the development of sustainable tourism as such products constitute a vital determinant for the decisions made in favour of space that is coherently and clearly organised. One of the key factors of spatial order is the aesthetic order because it affects the perception of space by the inhabitants and tourists, attracts investors and determines the attractiveness of a given area.

The temporary period of bear market, due to adverse economic transformations, on the one hand, negatively affected spatial development - here we can name deficiencies in social and technical infrastructure as well as migration of the inhabitants to larger towns to seek employment, yet, on the other hand, it also prevented certain adverse phenomena that arise alongside a dynamic growth of newcomers (e.g. sprawl with no clear borderlines) and a dynamic growth of tourism (new development prevailing to the detriment of regional 
forms of architecture). The key assets of the natural and cultural landscape of the municipality have remained unspoilt, yet require effective protection.

\section{Case Stude - FBC for Złotego Stoku}

The first stage of the research was intended to provide the answer to the question whether current planning documents to a sufficient extent guarantee the protection of natural and cultural landscape assets. For that purpose, a multiple-criteria analysis covering the provisions of the Study of Land Use Conditions and Directions of Spatial Development of the Municipality and the Local Zoning Plan was carried out. The students of the Faculty of Architecture of Poznan University of Technology ${ }^{4}$ have compared the Study of Land Use Conditions and Directions of Spatial Development with the local zoning plan, with all its changes, to find out the areas where hypothetically land development transformations could be observed. Another task was to compare the identified areas with the areas of inconsistencies between a plan drawing and an orthophotomap. This analysis has identified 26 areas whose landscape assets have failed to be effectively protected by the provisions of the local zoning plan.

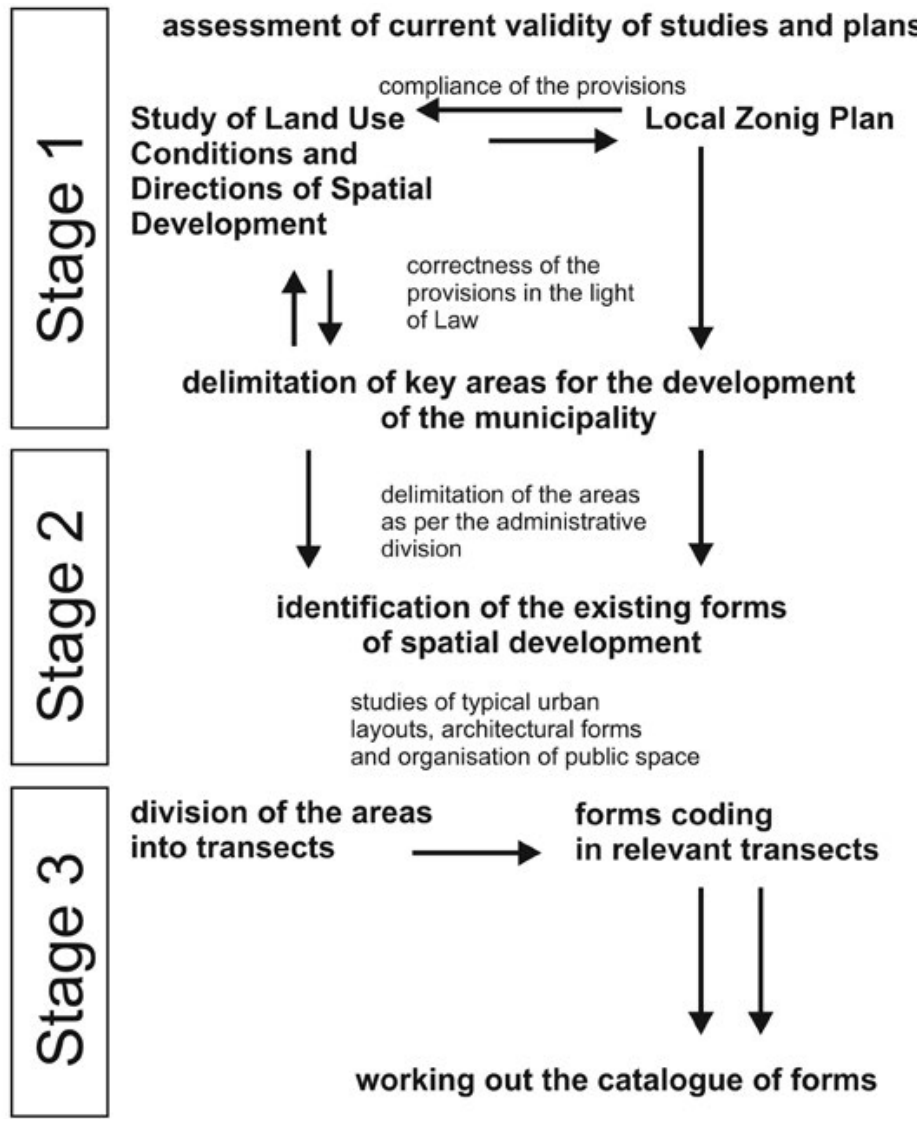

Fig. 3. Scheme of the research [author's own elaboration]

The analysis of the provisions of the local zoning plan has shown that the provisions concerning the principles of shaping development, delimitation of visual landscape protection zones, location of small architecture facilities and advertisements in public space, protection of the local, unique features of buildings as well as securing land strips for the technical and road infrastructure fail to be precisely worded. This stage of the research 
was concluded with the thesis that regulations that clearly and unambiguously define the scope and manner of completing investments in the municipality need to be introduced.

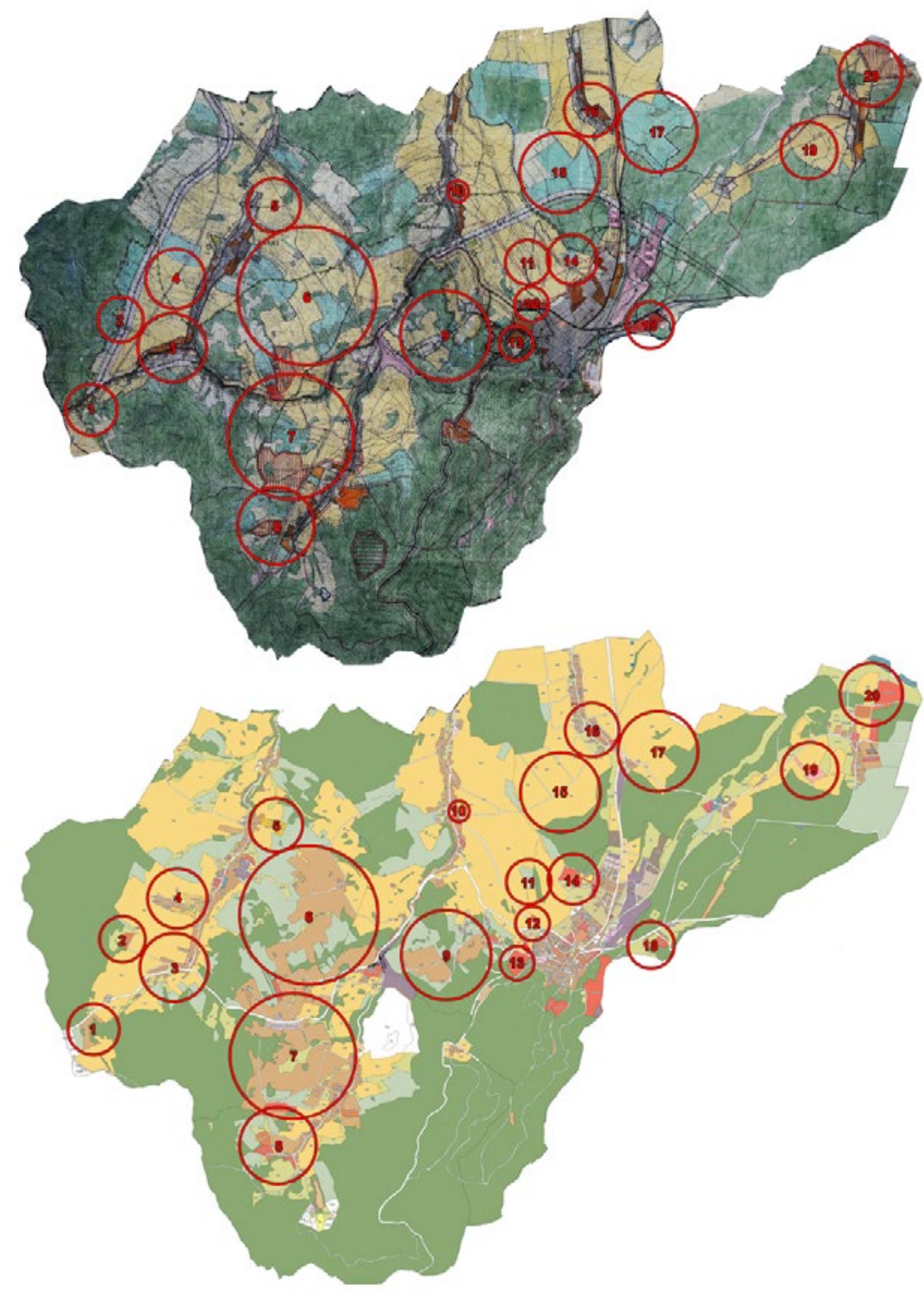

Fig. 4. Identification of key areas in the municipality of Złoty Stok [elaboration of the students of the Faculty of Architecture of Poznan University of Technology]

The next stage of the research was to identify the existing forms of spatial development to obtain information on architectural archetypes.

The field studies carried out by the students have allowed me to verify the actual status of the land use, to list the building complexes and single buildings being the most valuable assets and to identify the most urgent needs as regards organisation of public space. Urban planning inventory and photographic documentation were made for each of the administrative units of the municipality: the town of Złoty Stok and five villages. Having analysed the collected information, it was noted that the villages had to a large extent a similar structure and can be divided into transects from T1 to T4 and in two cases - to industrial zone. The town of Złoty Stok was the only settlement structure in the municipality with a clearly formed centre T5. 

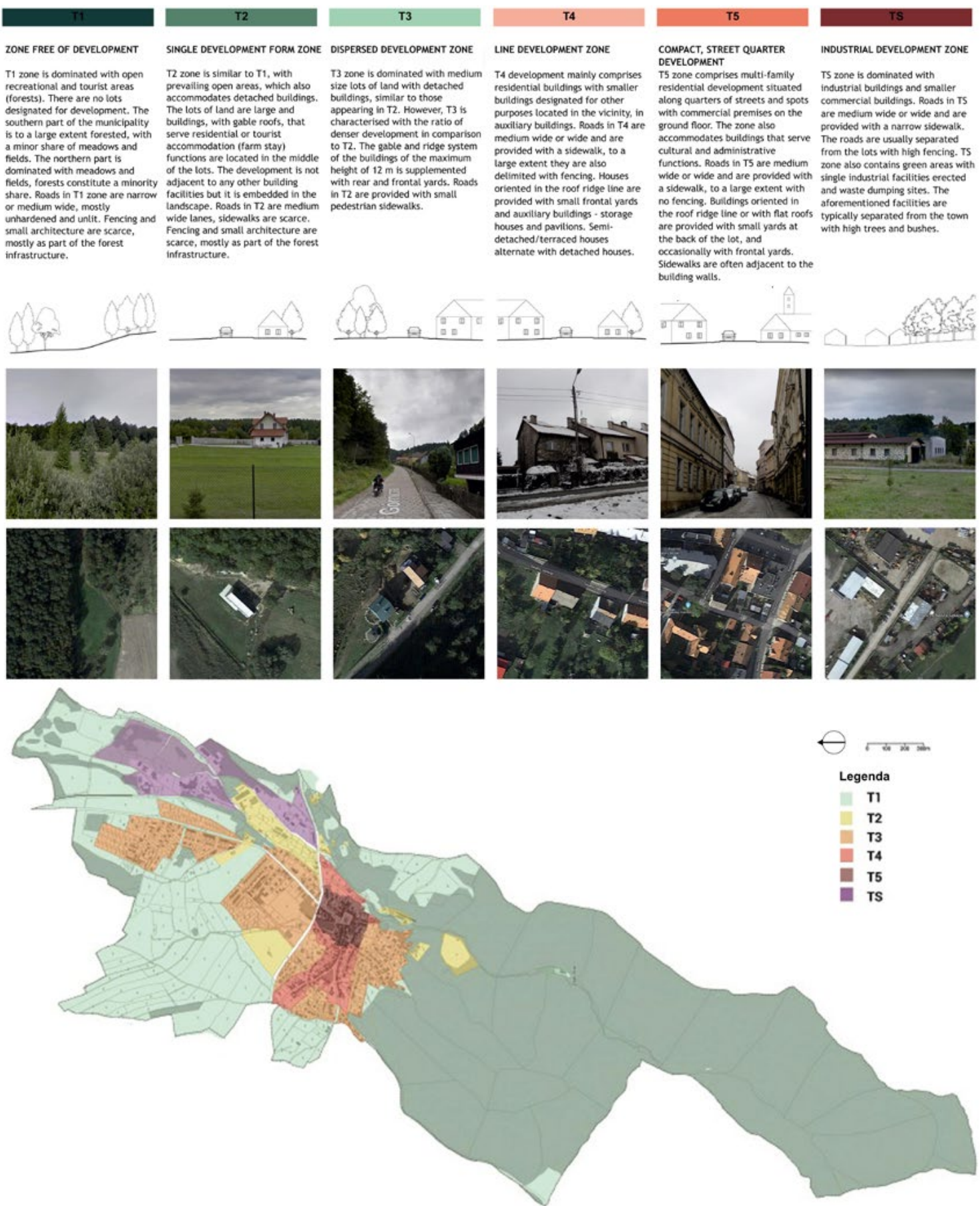
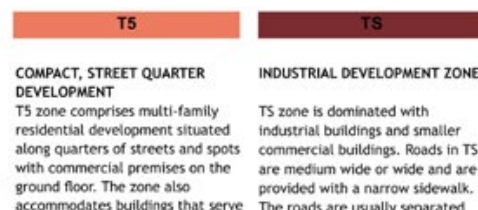

LINE DEVELOPMENT ZONE

T4 development mainly comprises residential buildings with smaller purposes located in the vicinity, in auriliary buildings Roads in $\mathrm{T} 4$ medium wide or wide and are provided with a sidewalk, to targe extent they are also delimited with fencing. Houses oriented in the roof rioge line are provided with small frontal yards and auxiliary bulldings - storage houses and pavitions. Sem. detached/terraced houses alternate with detached houses. accommodates buildings that functions. Roasds in TS are medium from the lots with high fencing. TS a sidewalk, to a large extent with single industrial facilities erected no fencing, Bulidings oriented in aforementioned faclities are the roof ridge line or with flat roofs typically separated from the town are provided with small yards at with high trees and bushes. the back of the lot, and occasionally with frontal yards. Sidewalks are often adjacent to the bullding walls.
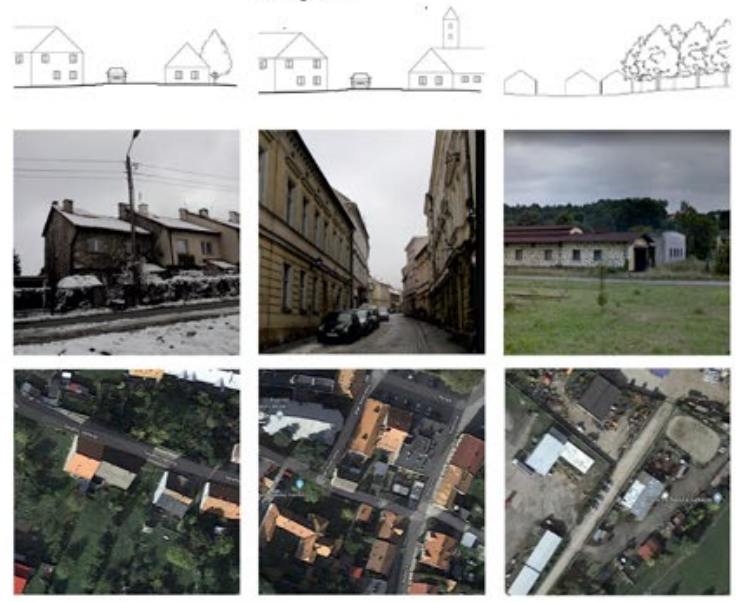

\begin{tabular}{r} 
Legend \\
T1 \\
T2 \\
T3 \\
T4 \\
T5 \\
\hline $\mathbf{T}$ \\
$\mathbf{T}$
\end{tabular} wide or wide and are provided with zone also contains green areas with

Fig. 5. Defined transects for the town of Złoty Stok [elaboration of the students of the Faculty of Architecture of Poznan University of Technology]

Finally, within the framework of the third stage of works, we have prepared relevant regulations in the form of a written catalogue. It has been decided that each village shall be individually approached as only such an approach would guarantee precise determination of forms of development in line with the needs of the local community and their aspirations. 


\section{Conclusions}

The so drawn-up analysis has been presented to the Town and Municipality Council for further discussions as it has been prepared with no participation of the local community but with the use of the expert method. A resolution of Złoty Stok Town and Municipality Council on joining FBC could trigger extensive activities aimed at better opportunities of development of sustainable tourism therein. The resources of the municipality can be in particularly enthreatened in view of designing tourist infrastructure components. Regulations introduced under $\mathrm{FBC}$ can prove an effective tool in counteracting adverse spatial phenomena. Owing to the presentation of the catalogue we have succeeded in drawing the attention of the inhabitants and officials to some vital aspects that might constitute good practice in working out local laws in future.

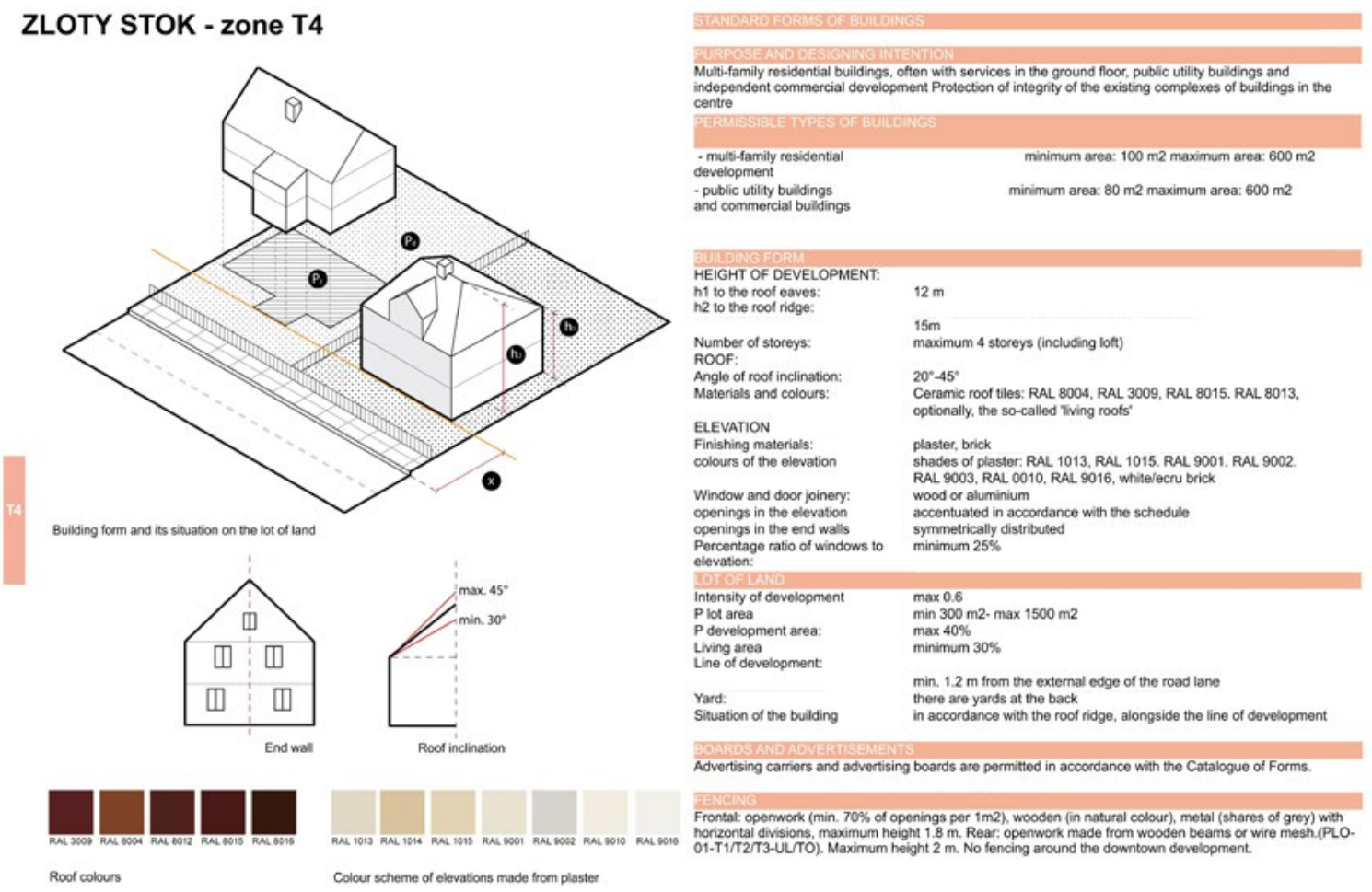

Fig. 6. Fragment of the catalogue of forms concerning private space in the town of Złoty Stok [elaboration of the students of the Faculty of Architecture of Poznan University of Technology]

Firstly, problems related to interpretation in the procedure of the issuance of a building permit in the Poviat Starosty must be eliminated. That is why the provisions of the local zoning plan shall clearly and unambiguously define the principles of shaping the development. Secondly, graphical appendices to the resolution on the local zoning plan, that graphically represent complex provisions thereof, should be so prepared that they were understandable not only for the professionals. Thirdly, the provisions of the zoning plan should equally concern private areas as well as public space because aesthetic and spatial order is one whole, with no division into property titles. Finally, land purpose should be demonstrated through interrelated and compact structures, whose borderlines are easy to be clearly defined. 


\section{References}

[1] Billert A., Likwidacja podmiotowości polskich miast i ich degradacja jako wynik błędnej polityki rozwoju państwa. Zielone wiadomości. Warsaw 2015.

[2] Duany A., Plater-Zyberk E., Towns and town making principles. Rizzoli, New York 2009.

[3] Gołębski G., Kompendium wiedzy o turystyce, PWN, Warsaw 2009.

[4] Hirt, S., To Zone or Not to Zone? Comparing European and American Land-use Regulation. PNDonline II, 2010.

[5] Jędraszko A., Zagospodarowanie przestrzenne w Polsce: drogi i bezdroża regulacji ustawowych. Unia Metropolii Polskich Warsaw 2005.

[6] Jopek D., Strefowanie jako narzędzie kształtowania struktury przestrzennej miasta. Studia KPZK nr 161, Warsaw 2015.

[7] Kaźmierczak B., Turystyka zrównoważona jako istotny czynnik aktywizacji małych miast. Teka Kom. Arch. Urb. Stud. Krajobr. - OL PAN, 2011.

[8] Kowalewski A., Gospodarka przestrzenna kryzys - źródła - straty - drogi wyjścia, Warsaw 2019.

[9] Parolek D., Karen C., Paul C., Form-Based Codes, a guide for planners, urban designers, municipalities and developers. Wiley, New York 2008.

[10] Pawłowska K., Idea swojskości w urbanistyce i architekturze miejskiej. PK, Krakow 1996.

[11] Woźniak M., Ład przestrzenny jako paradygmat zrównoważonego gospodarowania przestrzenią, Białostockie Studia Prawnicze, z. 18, 2015.

[12] Zachariasz I., Nowelizacja prawa planowania i zagospodarowania przestrzennego. in: Sprawne Państwo - propozycje zmian w funkcjonowaniu jednostek samorządu terytorialnego w Polsce. Editted by Kopyciński P., MSAP, Kraków 2015. 